\title{
Metabolic cold adaptation and aerobic performance of blue mussels (Mytilus edulis) along a temperature gradient into the High Arctic region
}

\author{
Jakob Thyrring • Søren Rysgaard - Martin E. Blicher • \\ Mikael K. Sejr
}

Received: 11 June 2014 / Accepted: 4 November 2014

(C) Springer-Verlag Berlin Heidelberg 2014

\begin{abstract}
The blue mussel (Mytilus edulis) has recently expanded its northern distribution in the Arctic and is therefore considered to be a sensitive indicator of climate changes in this region. In this study, we compared aerobic performance of blue mussels from High Arctic, Subarctic and temperate populations at different temperatures. Standard metabolic rates (SMR) and active metabolic rates (AMR) were measured for each population, and absolute $(A M R-S M R)$ and factorial $\left(\frac{A M R}{S M R}\right)$ scopes were calculated. Blue mussels from the temperate population had the lowest $\mathrm{Q}_{10}(=1.8)$ and the largest thermal window $(-1$ to $25{ }^{\circ} \mathrm{C}$ ), whereas $\mathrm{Q}_{10}$ values in the Arctic populations were 1.9 (Subarctic) and 2.3 (High Arctic), with a thermal window of -1 to $21^{\circ} \mathrm{C}$. Aerobic scope increased with rising temperatures, reaching a maximum at $14{ }^{\circ} \mathrm{C}$ (temperate) and $7{ }^{\circ} \mathrm{C}$ (Subarctic and High Arctic, respectively), after which a decrease was observed at temperatures exceeding $14{ }^{\circ} \mathrm{C}$. At low temperatures $\left(-1{ }^{\circ} \mathrm{C}\right)$, the average SMR of the High Arctic population was $93 \%$ higher than that of the temperate population and $22 \%$ higher than that of the Subarctic population. Combined, our results demonstrate
\end{abstract}

Communicated by H. Pörtner.

J. Thyrring $(\bowtie) \cdot$ S. Rysgaard $\cdot$ M. K. Sejr

Department of Bioscience, Arctic Research Centre,

Aarhus University, C. F. Møllers Allé 8, building 1110,

8000 Aarhus C, Denmark

e-mail: thyrring@bios.au.dk

S. Rysgaard · M. E. Blicher · M. K. Sejr

Greenland Climate Research Centre, Greenland Institute

of Natural Resources, Nuuk, Greenland

S. Rysgaard

Centre for Earth Observation Science, University of Manitoba,

Winnipeg, Manitoba, Canada physiological adaptation and plasticity of blue mussels across latitudes spanning from 56 to $77^{\circ} \mathrm{N}$. This indicates that low ocean temperature per se does not constrain metabolic activity of Mytilus in the Arctic; rather, we speculate that maturation of reproductive tissues, larval supply and annual energy budgets are the most relevant factors influencing Mytilus populations near their northern distributional edge in the Arctic.

\section{Introduction}

In the Arctic, recent ocean warming has occurred at a faster rate than the global average (Serreze et al. 2009). Warming of the oceans is affecting species distribution, genetics, phenology, ecology and physiology (Bradshaw and Holzapfel 2001; Pörtner 2002b; Parmesan 2007; Both et al. 2009; Sinervo et al. 2010). The continued warming of the Arctic is predicted to facilitate northward expansion of temperate-boreal species into the region, while the southern distributional limit of Arctic species is retracted (Walther et al. 2002; Węsławski et al. 2011). A biogeographic expansion of key species (e.g. blue mussels, snow crabs and great blacked gulls) has already taken place in the Arctic (Berge et al. 2005; CAFF 2013). In 2004, Berge et al. (2005) discovered scattered subtidal blue mussels (Mytilus edulis) on Svalbard after approximately 1,000 years of absence, presumably due to warmer ocean temperatures. Also, the intertidal distribution of blue mussels has shifted in a poleward direction, with the southern edge contracted by estimated $350 \mathrm{~km}$ since 1950 due to high temperature mortality (Jones et al. 2010). However, whereas the distributional limits and the physiological mechanisms involved in determining the southern limit [e.g. heat stress (Jones et al. 2010; Wernberg et al. 2013)] are well studied, much less is 
known about northern limits of boreal species in the Arctic and the physiological constraints and adaptations related to low temperatures.

At high latitudes, cold water slows down metabolic processes, and eurythermal marine invertebrates with a large geographic distribution may exhibit pronounced differences in physiological adaptation between populations from Arctic and temperate waters (Sukhotin et al. 2006). Studies on latitudinal variation in metabolic rate among ectothermic species have led to the hypothesis of metabolic cold adaptation (MCA) and evolutionary temperature adaptation (Krogh 1916; Holeton 1974; Addo-Bediako et al. 2002; Clarke 2003). Both hypotheses predict that species adapt physiologically to the low environmental temperature, and the MCA, in specific, states that ectotherms living in a constantly cold environment will have significantly elevated metabolic rates compared to species from warmer waters (Scholander et al. 1953; Holeton 1974). The MCA hypothesis has been proposed for stenothermal Antarctic fishes which over the last 25 million years of isolation in the Southern Ocean have evolved cells, enzymes and metabolic processes, adapted to enhance swimming activity, physiological processes and survival in a constantly cold environment (annual variation $<3{ }^{\circ} \mathrm{C}$; Torres and Somero 1988; Livermore et al. 2004). The MCA hypothesis was expanded to include Arctic and Antarctic marine invertebrates whose increased metabolic rates were shown to aid predatory avoidance, increase growth rates and allow organisms to complete life cycles in the short productive summer that characterizes high latitude areas (Pörtner and Playle 1998; Davenport 2000; Sommer and Pörtner 2002). The controversial hypothesis of MCA has been challenged and rejected with reference to observed differences in metabolic rates being ascribed to measurement artefacts and confounding effects from interspecies comparison and experimental protocols (Holeton 1974; Peck and Conway 2000). However, the MCA hypothesis has continually been re-emphasized, and whether or not MCA is a general feature of ectotherms inhabiting low-temperature environments remains uncertain (Pörtner 2002a; Schaefer and Walters 2010; White et al. 2012). So far, most studies on adaptation to low temperatures have compared physiological traits between multiple species, but little is known about intraspecific trade-offs and physiological adaptation and plasticity of ectothermic marine invertebrates living within and outside the Arctic region.

Physiological optimization to a life at low temperatures involves protein modification, as well as adjustments in enzyme activity, making cold-adapted species or populations more sensitive to increasing temperatures compared to their warmer counterparts (Nielsen et al. 1999; DoucetBeaupre et al. 2010; Zwerschke et al. 2013). Another possible side effect of living in a cold, thermally stable environment is a reduced ability to (physiologically) cope with acute or chronic temperature variation (Somero and Devries 1967; Peck et al. 2009b). At either end of the thermal range, a mismatch between oxygen uptake and requirement will occur, lowering aerobic scope (the degree to which oxygen consumption $\dot{M}_{O_{2}}$, can be increased above resting levels) which leaves less energy for reproduction and growth (Pörtner 2002a, b; Pörtner and Knust 2007). A decreased aerobic performance at increasing water temperature has implications for individual performances, population dynamics and species distribution (Munday et al. 2008; Pörtner and Farrell 2008). Observed changes in distribution range of mobile species (e.g. fish) support the notion that many species are sensitive to changing temperatures, leaving sessile and semi-sessile organisms extremely vulnerable to changes as they are restricted from migration (Peck 2005; Perry et al. 2005; Wernberg et al. 2013).

In this study, we tested aerobic performance of the blue mussel (M. edulis) from three different populations and quantified their short-term metabolic response to increased water temperatures. Specifically, we investigated intraspecific metabolic cold adaptation and the effect of adaptation to the Arctic climate on the upper thermal limits for stable oxygen uptake $\left(\mathrm{T}_{\max }\right)$ and aerobic scope under rising water temperatures. M. edulis is an ideal organism for studying macrophysiological traits on a large spatial scale, being semi-sessile and widely distributed throughout circumpolar Arctic and temperate waters. We compared populations from three different climate zones represented by Denmark (temperate), South Greenland (Subarctic) and North Greenland (High Arctic), and this study provides one of the first insights into the performance, adaptability and capability of a semi-sessile species, which has expanded to and inhabited the High Arctic region.

\section{Materials and methods}

Collection sites, animals and holding conditions

This study was conducted on mussels (M. edulis) collected in the lower intertidal zone at three geographic locations during the Arctic summer: (1) The Bowdoin Fjord near Qaanaaq (High Arctic Greenland, $77^{\circ} \mathrm{N}$ ); (2) the Kobbefjord near Nuuk (Subarctic Greenland, $64^{\circ} \mathrm{N}$ ) and (3) Aarhus Bay (temperate Denmark, $56^{\circ} \mathrm{N}$ ). At the High Arctic site, the fjord is covered by sea ice approximately 9 months a year (Sejr et al. 2009), and water temperature is below $-1{ }^{\circ} \mathrm{C}$ throughout the year except during July, August and September where a maximum temperature of $5{ }^{\circ} \mathrm{C}$ is reached (10 m depth; Krause-Jensen et al. 2012). In the Subarctic Kobbefjord, only a small fraction of the inner part of the fjord is ice-covered, usually from January 
to May, and water temperature is above $0{ }^{\circ} \mathrm{C}$ (with a maximum of $14{ }^{\circ} \mathrm{C}$ ) except from January to April (Olesen et al. 2014). In Aarhus Bay, water temperature can be above $0{ }^{\circ} \mathrm{C}$ throughout the year and above $10{ }^{\circ} \mathrm{C}$ from April to October, with a maximum of $20^{\circ} \mathrm{C}$ at $5 \mathrm{~m}$ depth (Jørgensen and Richardson 1996).

Mussels were collected in July and August 2013. Adult mussels with a shell length of $45-55 \mathrm{~mm}$ were collected and transported to holding facilities at Aarhus University, Denmark, within 2 days of collection. Animals were kept in $40 \mathrm{~L}$ aquariums of similar salinity (27 PSU) as the collection site. Aquarium water temperatures were lowered to holding temperature $\left(1^{\circ} \mathrm{C}\right)$ at a rate of $1{ }^{\circ} \mathrm{C}$ day ${ }^{-1}$, using $0.5{ }^{\circ} \mathrm{C}$ steps in the morning and afternoon (Peck et al. 2009a). Mussels were allowed to acclimate to laboratory conditions for 4 weeks prior to respiration measurements, and water temperature was maintained at $1 \pm 0.20{ }^{\circ} \mathrm{C}$ throughout the experimental period. Mussels were fed weekly with commercially available phytoplankton mix (Reed Mariculture, Shellfish Diet—1,800 Formula, Campbell, CA, USA), with half the water volume exchanged with fresh filtrated seawater to minimize the build-up of pseudofeces and excretion products. Mussels were cleaned of all epibiota and starved for $72 \mathrm{~h}$ prior to experiments (Hatcher et al. 1997; Begum et al. 2009).

\section{Experimental set-up}

Rates of oxygen consumption $\left(\dot{M}_{O_{2}}\right)$ were measured using closed-bottle respirometry modified from the methods described by Sejr et al. (2004) and Watson et al. (2014). The experimental set-up consisted of four Plexiglas respirometers $(653 \mathrm{~mL})$ submerged in a darkened tank, containing $40 \mathrm{~L}$ fully aerated seawater with a salinity of 27 PSU. Experiments were conducted in a temperaturecontrolled system with water temperature controlled to a maximum variation of $\pm 0.2{ }^{\circ} \mathrm{C}$. Submersible pumps ensured a constant flow of fully aerated seawater inside the holding tank, and inside respirometers, water mixing was ensured by a $3-\mathrm{cm}$ Teflon-coated magnetic stir bar adjusted to $60 \mathrm{rpm}$. Oxygen concentration of the respirometer water was measured constantly $\left(1 \mathrm{~s}^{-1}\right)$, using fibre optic leads focused on contactless oxygen sensor patches which were attached with silicone grease inside each chamber (FireSting $\mathrm{O}_{2}$, Pyro Science, Aachen, Germany).

\section{Respirometry protocol}

The rate of oxygen consumption was measured at $-1,0,1,7$, $14,21,25$ and $30{ }^{\circ} \mathrm{C}$ (or until mussels began losing constant oxygen uptake) to establish standard metabolic rates (SMR) and active metabolic rates (AMR) at temperatures approaching the thermal limit of this species. All $\dot{M}_{\mathrm{O}_{2}}$ measurements were performed during daylight hours and repeated three times per mussel. The same 12 specimens from each population were used at all temperature trials. We transferred animals from the holding tank $\left(1^{\circ} \mathrm{C}\right)$ to the respirometer chambers $\left(1{ }^{\circ} \mathrm{C}\right)$ by keeping specimens submerged at all time to minimize stress. A single mussel was placed inside each of the respirometers and allowed $1 \mathrm{~h}$ to acclimate before water temperature was adjusted at a rate of $1{ }^{\circ} \mathrm{C} \mathrm{h}^{-1}$ to reach experimental temperature $\left(-1,0,1,7,14,21,25\right.$ or $\left.30^{\circ} \mathrm{C}\right)$, using a submersible heater (JULABO GmbH, Seelbach, Germany). Respirometers had a constant circulation of fresh, fully aerated seawater during the acclimation and temperature adjustment period. At experimental temperature, mussels were left for an additional hour before respirometers were sealed (without disturbing the animals) and $\dot{M}_{\mathrm{O}_{2}}$ measurements initiated. During $\dot{M}_{\mathrm{O}_{2}}$ measurements, all specimens had constant rates of oxygen consumption. The mussels were incubated for variable amounts of time, but incubations always ended before the oxygen content of the water was depleted below $85 \%$ air saturation (Jansen et al. 2007).

Active metabolic rates (AMR) were measured during feeding, as this has been shown to represent the activity of semi-sessile suspension-feeding animals (Thompson and Bayne 1972; 1974; Gaffney and Diehl 1986). Mussels were incubated with an initial algae concentration of 20.000 cells $\mathrm{mL}^{-1}$ to ensure optimal feeding activity, maximum metabolic increase and reduced production of pseudofeces during the short experimental period (Riisgård and Randlov 1981). All AMR measurements were made within the first 30 min of incubation. Upon completion of SMR and AMR measurements, the temperature in the experimental tank was reverted to $1{ }^{\circ} \mathrm{C}$ at a constant rate of $1{ }^{\circ} \mathrm{C} \mathrm{h}^{-1}$. The mussels were then returned to holding tanks for 5 days of recovery time, during which they were fed to saturation the first 2 days, followed by $72 \mathrm{~h}$ of starvation prior to the next experiments. Upon completion of SMR and AMR measurements replicates, the animals were carefully removed, and all the soft tissue was dissected out and measured on a digital scale, and a conversion to dry weight was made based on Ricciardi and Bourget (1998). After animal removal, the background respiration in each respirometer was recorded for another $2 \mathrm{~h}$ to determine microbial oxygen demand (i.e. from animal waste products). In addition, background respiration was measured (both during SMR and AMR) in an empty chamber at all experimental temperatures. Background respiration was subtracted prior to any further analysis. After respiration measurements were completed, 10-12 specimens from each population were screened for their reproductive stage. In none of the populations, mature reproductive tissues were found, indicating that spawning had occurred prior to collection in the field, or alternatively, that environmental conditions had not allowed maturation of gonads. 
Statistical analysis

Oxygen consumption was calculated from the decline in oxygen concentration in chambers, using the mean of the three individual $\dot{M}_{O_{2}}$ measurements. For each mussel, aerobic scope was calculated as $(A M R-S M R)$ and factorial scope as $\frac{A M R}{S M R}$. All oxygen consumption data are presented as mean \pm standard error. To compare differences in SMR, AMR, $\mathrm{Q}_{10}$ and scope between temperatures, one-way ANOVAs followed by Tukey's HSD analysis were used. Variance of homogeneity was tested using Bartlett's and Brown-Forsythe tests, and data were logtransformed when necessary to ensure variance homogeneity and normally distributed data. All statistical tests were conducted using $\mathrm{R}$ ( $\mathrm{R}$ Development Core Team 2013). Mean values were considered significantly different when $p<0.05$.

\section{Results}

Blue mussels from the temperate $\left(56^{\circ} \mathrm{N}\right)$, Subarctic $\left(64^{\circ} \mathrm{N}\right)$ and High Arctic $\left(77^{\circ} \mathrm{N}\right)$ populations exhibited a significant increase in SMR between 1 and $21^{\circ} \mathrm{C}$ (Fig. 1). SMR $\mathrm{Q}_{10}$ coefficients of between -1 and $14{ }^{\circ} \mathrm{C}$ were 1.8 (temperate), 1.9 (Subarctic) and 2.3 (High Arctic), respectively. $Q_{10}$ values revealed that the High Arctic population were the most sensitive to temperature changes, as compared to the Subarctic and temperate populations (ANOVA: $\mathrm{F}_{2,36}=5.19 ; p=0.0104$ ). At $30{ }^{\circ} \mathrm{C}$, only mussels from the temperate population opened their valves, whereas Subarctic and High Arctic mussels had closed valves, for which reason no oxygen measurements were made. SMR for all three populations increased until the upper thermal limit $\left(\mathrm{T}_{\max }\right)$ for aerobic performance was reached after which SMR decreased. $\mathrm{T}_{\max }$ for the temperate population was $25^{\circ} \mathrm{C}$ (Fig. 1a), and for both the Subarctic and High Arctic populations, $\mathrm{T}_{\max }$ was $21{ }^{\circ} \mathrm{C}$ (Fig. 1b, c). AMR followed the same trend as SMR; the AMR was highest for all populations at $14{ }^{\circ} \mathrm{C}$, after which it decreased significantly (Fig. 1), except for the High Arctic population in which no differences were detected between 14 and $21^{\circ} \mathrm{C}$ (Fig. 1c).

For all three populations, aerobic scopes increased with temperature until a maximum was reached. For temperate specimens, a significant increase in aerobic scope was found between temperatures from 1 to $14{ }^{\circ} \mathrm{C}$ (Fig. 2a). The aerobic scope increased from 0.11 to $2.52 \mathrm{mg} \mathrm{O}_{2} \mathrm{~g}^{-1} \mathrm{~h}^{-1}$ (Fig. 2a), and the factorial aerobic scope increased by 1.1 from 1.8 to 2.9 (Fig. 2b). The Subarctic population showed a significant increase in aerobic scope from 1 to $7^{\circ} \mathrm{C}$ before reaching a plateau (Fig. 2c). The aerobic scope was highest at $14{ }^{\circ} \mathrm{C}$ with a $460 \%$ increase from $0.20 \mathrm{mg} \mathrm{O}_{2} \mathrm{~g}^{-1} \mathrm{~h}^{-1}$ at
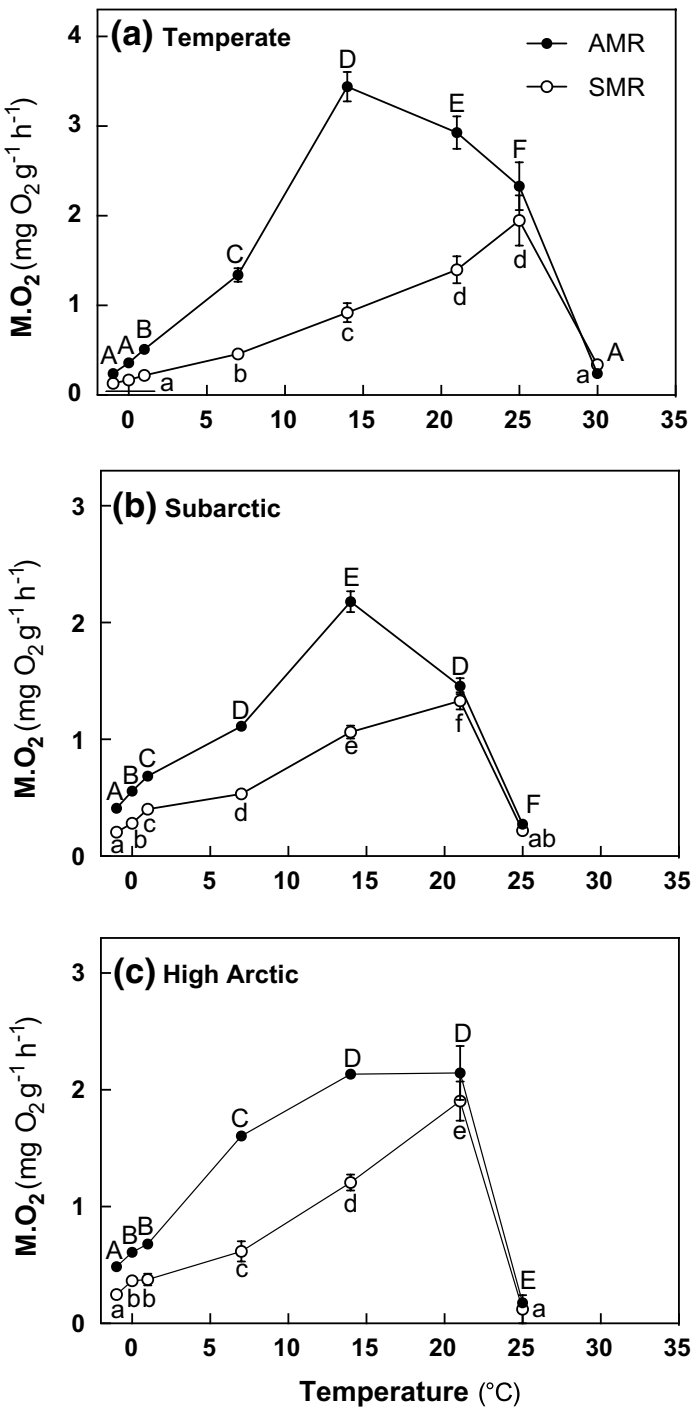

Fig. 1 Active metabolic rates (black circles) and standard metabolic rates (white circles) of oxygen consumption $\left(\dot{M}_{\mathrm{O}_{2}}, \mathrm{mg} \mathrm{O}_{2} \mathrm{~g}^{-1} \mathrm{~h}^{-1}\right)$ of acutely exposed blue mussels (Mytilus edulis) from three geographic locations at different temperatures: a Temperate $\left(56^{\circ} \mathrm{N}\right)$; b Subarctic $\left(64^{\circ} \mathrm{N}\right)$ and c High Arctic $\left(77^{\circ} \mathrm{N}\right)$. Data are presented as mean \pm standard error, $n=12$ for each temperature at all locations. Different capital letters indicate significant differences between active rates $(p<0.05)$, whereas different lowercase letters indicate significant differences between resting rates $(p<0.05)$

$-1{ }^{\circ} \mathrm{C}$ to $1.12 \mathrm{mg} \mathrm{O}_{2} \mathrm{~g}^{-1} \mathrm{~h}^{-1}$. The factorial scope increased from $2\left(-1{ }^{\circ} \mathrm{C}\right)$ to $2.54\left(7{ }^{\circ} \mathrm{C}\right.$; Fig. $\left.2 \mathrm{~d}\right)$. Aerobic scope of the High Arctic population increased from 1 to $7{ }^{\circ} \mathrm{C}$, reaching a plateau between 7 to $14{ }^{\circ} \mathrm{C}$, after which a significant decrease was found at temperatures above $14{ }^{\circ} \mathrm{C}$ (Fig. 2e). The aerobic scope between 1 and $7^{\circ} \mathrm{C}$ increased from 0.24 to $0.98 \mathrm{mg} \mathrm{O}_{2} \mathrm{~g}^{-1} \mathrm{~h}^{-1}$. The highest factorial scope was 2.6 found at $7^{\circ} \mathrm{C}$ (Fig. 2f).

Finally, to test for the presence of metabolic cold adaptation, a comparison of SMR between blue mussels from all 

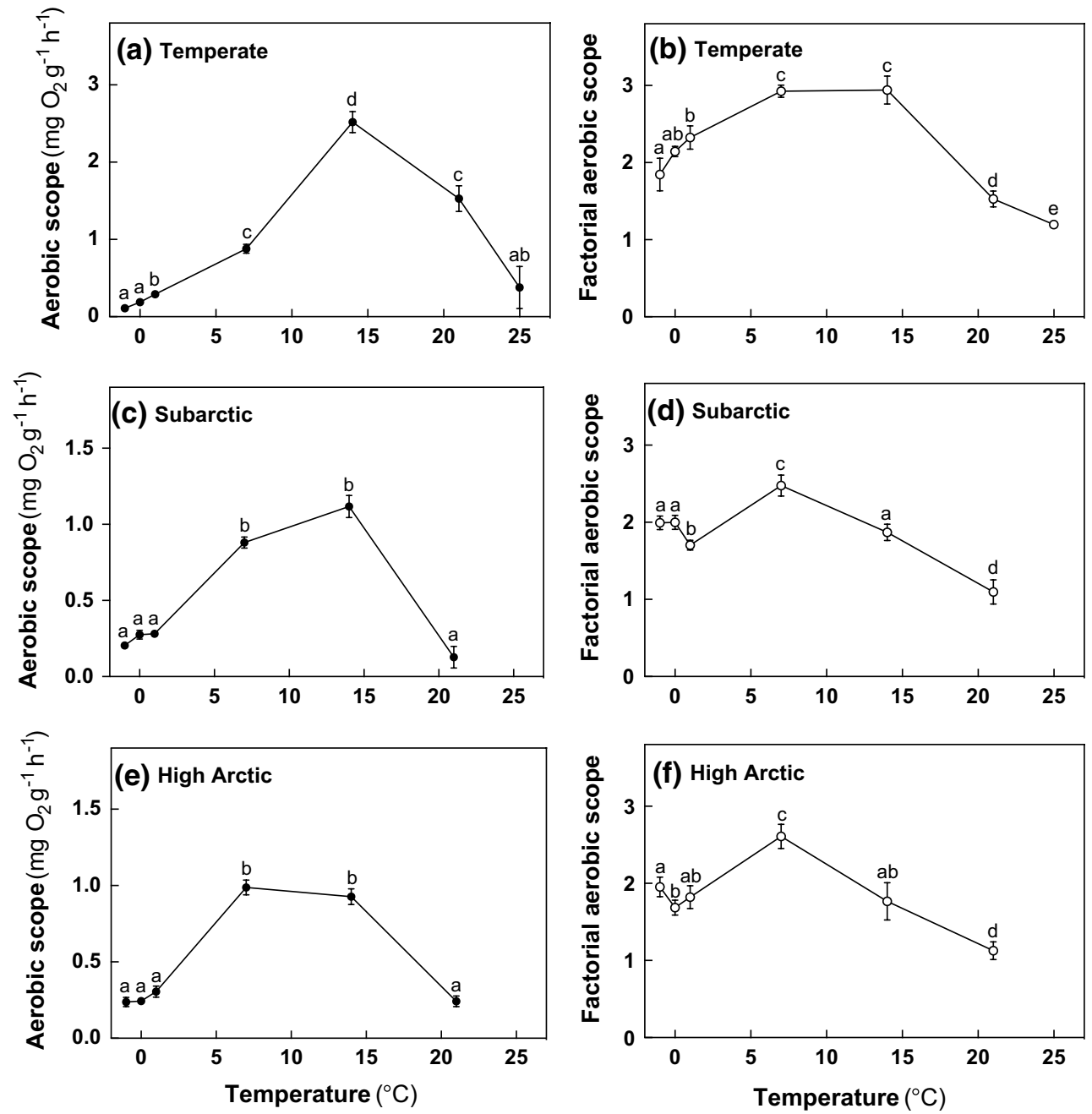

Fig. 2 Aerobic scope (black circles) and factorial scope (white circles) for blue mussels (Mytilus edulis) from three geographic locations at different temperatures: a, b Temperate region $\left(56^{\circ} \mathrm{N}\right)$; $\mathbf{c}, \mathbf{d}$ Subarctic region $\left(64^{\circ} \mathrm{N}\right)$ and e, f High Arctic region $\left(77^{\circ} \mathrm{N}\right)$. Data are

three locations was made at $-1,0,1$ and $7{ }^{\circ} \mathrm{C}$ (Fig. 3). We found a significant increase in oxygen consumption rates towards higher latitude: High Arctic $>$ Subarctic $>$ Temperate (ANOVA: $\mathrm{F}_{2,141}=14.29 ; p<0.001$ ). On average, the SMR of blue mussels collected at the High Arctic site were $93 \%$ higher than that of the temperate population and $22 \%$ higher than that of the Subarctic population, when compared at $-1{ }^{\circ} \mathrm{C}$.

\section{Discussion}

This study shows considerable physiological adaptation and plasticity in blue mussels (M. edulis) along a latitudinal gradient. Latitudinal variation was observed among all three populations of $M$. edulis from the temperate, presented as mean \pm standard error, $n=12$ for each temperature at all locations. Different lowercase letters indicate significant differences between temperatures $(p<0.05)$

Subarctic and High Arctic region. Our temperate population had a lower $\mathrm{Q}_{10}\left(\mathrm{Q}_{10}=1.8\right)$ compared to the Arctic populations. Blue mussels from the Arctic had $\mathrm{Q}_{10}$ values of 1.9 (Subarctic) and 2.3 (High Arctic). Such a poleward increase of $\mathrm{Q}_{10}$ values correlate well with a study by Jansen et al. (2007) on blue mussels along a temperature gradient across Europe. Jansen et al. (2007) showed an increase in $\mathrm{Q}_{10}$ values in summer-acclimated blue mussels from below 1 in the south to $\sim 2$ in the north, corresponding to the latitude of our Subarctic population $\left(64^{\circ} \mathrm{N}\right)$. On an enzymatic level, Doucet-Beaupre et al. (2010) found higher $\mathrm{Q}_{10}$ values of 10 metabolic enzymes in a Subarctic population, compared to that of a temperate population of two closely related mussel species. We found higher $\mathrm{Q}_{10}$ values in the High Arctic population compared with the temperate counterpart, and this support the general 


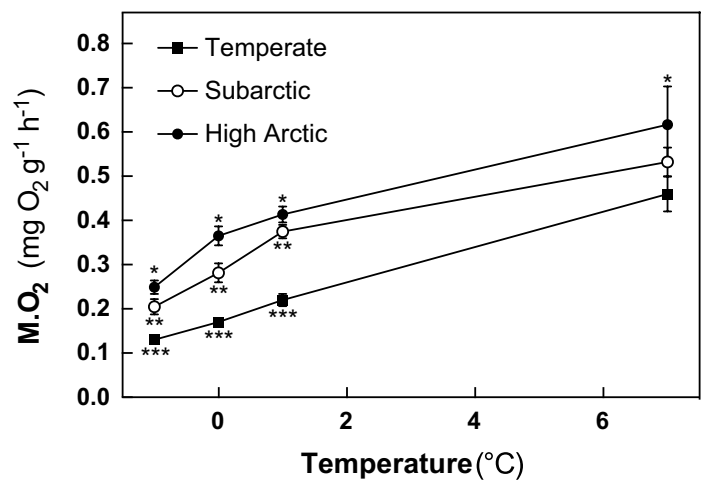

Fig. 3 Relationship between standard metabolic rates of oxygen consumption $\left(\dot{M}_{\mathrm{O}_{2}}, \mathrm{mg} \mathrm{O}_{2} \mathrm{~g}^{-1} \mathrm{~h}^{-1}\right)$ at $-1,0,1$ and $7{ }^{\circ} \mathrm{C}$ for three geographic locations of blue mussel (Mytilus edulis) populations. Data are presented as mean \pm standard error, $n=12$ for each location. Different stars indicate significant differences in oxygen consumption between populations tested at temperatures $-1,0,1$ and $7{ }^{\circ} \mathrm{C}$ between locations $(p<0.05)$

increase in thermal sensitivity towards higher latitudes from the temperate to the High Arctic region. Indeed, as temperatures increased, the SMR of the Arctic populations increased at a higher rate, compared to that of the temperate population. These results correspond with recent work by Peck et al. (2014), revealing a greater effect of rising temperatures on the SMR of polar and tropical ectothermic species, as compared to that of their counterparts from intermediate latitudes (see also Nguyen et al. 2011). The observed poleward increase in temperature effects on SMR among populations could affect their sensitivity to high water temperatures, as known from stenotherm ectotherms (Pörtner 2006). Pörtner (2006) described how cold-adapted stenothermic ectotherms have a narrow thermal window as a trade-off from conserving energy by the loss of, e.g. haemoglobin and heat shock proteins. This corresponded with a review by Peck (2005) on thermal tolerance of Antarctic ectotherms that revealed animals died when temperatures was raised by only $5-10{ }^{\circ} \mathrm{C}$ above annual average. To investigate if patterns are the same in cold-adapted eurythermic blue mussels, we determined the upper thermal limit $\left(\mathrm{T}_{\max }\right)$, where the remaining aerobic scope is insufficient to support metabolic processes. We found the temperate population had the highest $\mathrm{T}_{\max }\left(25^{\circ} \mathrm{C}\right)$ with a larger thermal window $\left(-1\right.$ to $25^{\circ} \mathrm{C}$ ), as compared to the Sub- and High Arctic populations, which had a thermal window of -1 to $21^{\circ} \mathrm{C}$. This clearly indicate that cold-adapted eurythermic blue mussels maintain a high thermal window despite annual low temperatures, contradicting the patterns found in Antarctic stenothermic ectotherms. However, as $\mathrm{T}_{\max }$ values are well above the predicted future ocean temperature in the Arctic region (IPCC 2014), any differences in thermal tolerance between the populations studied may have limited ecological consequences.

The response of metabolic rates (SMR and AMR) and aerobic performances to temperatures is important for the Darwinian fitness of animals. SMR of Mytilus spp. is well studied in temperate regions, and SMR results from our temperate population were indeed consistent with previous work (Newell and Pye 1970; Hamburger et al. 1983; Jansen et al. 2007). Despite differences in mean habitat temperatures, all populations had the highest factorial scope at $7{ }^{\circ} \mathrm{C}$. The temperate population maintained a factorial scope of $\sim 3$ at $14{ }^{\circ} \mathrm{C}$, whereas the Subarctic and High Arctic populations both decreased to $\sim 2$. The capability to maintain a factorial scope of $\sim 3$ at $14{ }^{\circ} \mathrm{C}$ indicate that temperate mussels have a better aerobic performance at high temperatures than do the Arctic populations. The temperate population of blue mussels gets exposed to large temperature variations throughout the year. Their optimal aerobic performance between 7 and $14{ }^{\circ} \mathrm{C}$ may optimize feeding, reproduction and growth during spring and early summer when phytoplankton blooms and food is plenty. In the Arctic summer, mussels are exposed to water temperatures of $5-10{ }^{\circ} \mathrm{C}$ during a few months (Krause-Jensen et al. 2012). Our results quantified oxygen consumption in specimens sampled in this summer period. This study shows that Arctic populations have the highest aerobic performance at $7{ }^{\circ} \mathrm{C}$ (matching the habitat temperature), thus indicating that blue mussels are highly capable of adapting to the Arctic environment at their northernmost distribution limits. These results present a challenge to one of the leading hypotheses on temperature-sensitive mechanisms driving species distribution (i.e. the hypothesis of oxygenand capacity-limited thermal tolerance, OCLTT, by Pörtner and Knust 2007; Pörtner and Farrell 2008). According to the OCLTT, the aerobic scope of marine ectotherms will decrease towards distribution edges as habitat temperature becomes too extreme (Pörtner 2002b). Consequently, the OCLTT proposes that distribution limits and environmental niches are defined by limited overall animal aerobic performances. The present study does not support such a driver (i.e. aerobic performance) to limit the distribution of blue mussels in the Arctic. Despite the fact that low temperatures do not limit aerobic performance, the low Arctic temperatures may still be a key driver of limiting the distribution of Mytilus spp. Indeed, our study of adult mussels collected at High Arctic sites, which are characterized by water temperatures of $\sim-1.8^{\circ} \mathrm{C}$ for more than 9 months a year (unpublished data), show that low temperature per se does not influence survival at the northern edge. Still, low temperature could prevent the maturation of gonads. Thorarinsdottir and Gunnarsson (2003) showed that temperatures below $7{ }^{\circ} \mathrm{C}$ suppressed or completely stopped gonad development in Subarctic blue mussels. 
Additionally, there have been no reports of High Arctic blue mussels with developed gonads, nor has blue mussel spat ever been observed (Berge et al. 2005, Thyrring pers. obs.). All in all, reproduction and recruitment may determine the northern limit for Mytilus species. This could also explain why blue mussels are more abundant in Qaanaaq (High Arctic Greenland) than on Svalbard, in spite of both locations being at $77^{\circ} \mathrm{N}$ with lower water temperatures and longer ice cover in Qaanaaq (Berge and Thyrring pers. obs.). It is possible that the northward West Greenland Current and the continuous coastline facilitate an annual larval drift to optimal microhabitats in High Arctic Greenland, whereas Svalbard is isolated from spawning populations. This hypothesis was supported by Berge et al. (2005) who found M. edulis on Svalbard and suggested they had been dispersed there by the West Spitsbergen Current from Norway. However, knowledge about the distribution patterns of Mytilus spp. across the Arctic remains limited. Therefore, to fully understand the drivers of dispersal and reproduction, we urge new studies to focus on gonad development, genetic diversity and larval survival in cold-water environments.

Blue mussels found in the Arctic also showed physiological adaptations to the lowest water temperatures. The temperature-specific SMR increased along the temperature gradient from the temperate region towards the Arctic region. High Arctic mussels exhibited elevated SMR compared to that of both Subarctic and temperate populations. When evaluated at $-1,0$ and $1{ }^{\circ} \mathrm{C}$, the cold-adapted High Arctic population performed better than both the Subarctic and temperate populations. Increased SMR indicates a capability of blue mussels to adapt to, and compensate for, low water temperatures in high latitude populations. This provides evidence for intraspecific metabolic cold adaptation (MCA). MCA can be assessed at two levels: interspecific and intraspecific. So far, most MCA research (including meta-analytical studies) has focused on the interspecific level with contradicting results (Holeton 1974; Clarke 1980; Addo-Bediako et al. 2002; Watson et al. 2014). The process behind interspecific and intraspecific MCA may be very different. To a large extent, the contradicting results of interspecific MCA are driven by evolutionary adaptation to a life in constant low-temperature water, as proposed for Antarctic ectotherms (Wohlschlag 1960; Torres and Somero 1988). Antarctic stenothermal ectotherms have been isolated in the cold Southern Ocean for millions of years, and it is now well known that they have evolved (extremely) high mitochondrial densities, cold-optimized enzymes and an efficient energy turnover rate, allowing them to perform in low-temperature habitats (Johnston et al. 1998; Clarke and Johnston 1999; Davenport 2000). The opposite is true for temperate eurythermal species (e.g. blue mussels), which are evolutionary, adapted to a life in the temperate region with high seasonal temperature variations.

In Arctic Greenland, the oldest fossils of blue mussels ever found are dated 10,000 years BP; in East Greenland, however, blue mussels disappeared 6,000 years ago, presumably due to cooling of the climate (Hjort and Funder 1974). The recent re-colonization of blue mussels on a few High Arctic locations (including West Greenland and Svalbard) may be attributed to the warming of the region (Theisen 1973, Berge et al. 2005). Consequently, evolutionary adaptation is not a driver of intraspecific MCA in blue mussels; however, in the northern population of this species, local acclimation and adaptation may drive the patterns found. Edge populations often exhibit improved ability for specialization to the local environment, thus enhancing their ecological performance (Stillman 2003; Terblanche et al. 2009). It is possible that cold-adapted populations of eurythermal ectotherms have increased enzyme respiration and mitochondrial activity, leading to increased oxygen consumption, which affects survival, feeding and reproduction (Clarke 1987; Sommer and Pörtner 2002; Lannig et al. 2003). Consequently, annually elevated SMR of cold-adapted Arctic mussels indicates an increased energy requirement, not only in winter when food is limited, but also in summer at high temperatures (Clarke 1993). However, seasonal up- and down-regulation of metabolic processes are well known in bivalves (Hatcher et al. 1997; Jansen et al. 2007). The demand for ATP to maximize feeding for growth and energy storage during the productive season (summer) may increase oxygen consumption, and hence ATP production, in blue mussels (Clarke and Fraser 2004). In winter, primary production is absent, and energy consumption could be minimized by a down-regulated metabolism, combined with the use of stored triglyceride lipids for metabolic maintenance (Pernet et al. 2007). Unfortunately, very few data exist on the seasonal adaptation of Arctic bivalves, and more studies are needed to determine the physiological processes and ecological drivers affecting adaptability of the blue mussel.

In conclusion, this study provides evidence of significant metabolic adaptation to temperature between populations of M. edulis along a latitudinal gradient. Both the temperate the Subarctic and the High Arctic populations displayed constant metabolic activity over a wide temperature range. The upper thermal limit was slightly higher for the temperate population $\left(25^{\circ} \mathrm{C}\right)$, compared to that of the High Arctic and Subarctic populations $\left(21^{\circ} \mathrm{C}\right)$. For all three populations, the absolute aerobic scope declined at temperatures above $14{ }^{\circ} \mathrm{C}$. At low temperatures $\left(-1\right.$ to $\left.1{ }^{\circ} \mathrm{C}\right)$, metabolic rates increased with latitude, suggesting metabolic adaptation to low temperatures in Arctic M. edulis. Finally, our results indicated that low water temperature per se does not constrain the survival and distribution of this species in the Arctic region. 
Acknowledgments The study was financially supported by the 15 June Foundation. JT was supported by the Commission for Scientific Research in Greenland and Aase og Jørgens Münter's Foundation. The authors wish to thank Kattegatcentret for providing filtrated seawater. We gratefully acknowledge the contributions of Arctic Research Centre (ARC), Aarhus University. SR was supported by the Canada Excellence Research Chair (CERC). This work is a contribution to the Arctic Science Partnership (ASP) asp-net.org.

\section{References}

Addo-Bediako A, Chown SL, Gaston KJ (2002) Metabolic cold adaptation in insects: a large-scale perspective. Funct Ecol 16:332338. doi:10.1046/j.1365-2435.2002.00634.x

Begum S, Basova L, Strahl J, Sukhotin A, Heilmayer O, Philipp E, Brey T, Abele D (2009) A metabolic model for the ocean quahog Arctica islandica - effects of animal mass and age, temperature, salinity, and geography on respiration rate. J Shellfish Res 28:533-539. doi:10.2983/035.028.0315

Berge J, Johnsen G, Nilsen F, Gulliksen B, Slagstad D (2005) Ocean temperature oscillations enable reappearance of blue mussels Mytilus edulis in Svalbard after a 1000 year absence. Mar Ecol Prog Ser 303:167-175. doi:10.3354/Meps303167

Both $\mathrm{C}$, van Asch M, Bijlsma RG, van den Burg AB, Visser ME (2009) Climate change and unequal phenological changes across four trophic levels: constraints or adaptations? J Anim Ecol 78:73-83. doi:10.1111/j.1365-2656.2008.01458.x

Bradshaw WE, Holzapfel CM (2001) Genetic shift in photoperiodic response correlated with global warming. Proc Natl Acad Sci USA 98:14509-14511. doi:10.1073/Pnas.241391498

CAFF (2013) Arctic biodiversity assessment - status and trends in Arctic biodiversity. Conservation of Arctic Flora and Fauna, Akureyri, p 678

Clarke A (1980) A reappraisal of the concept of metabolic cold adaptation in polar marine invertebrates. Biol J Linn Soc 14:77-92. doi:10.1111/j.1095-8312.1980.tb00099.x

Clarke A (1987) Temperature, latitude and reproductive effort. Mar Ecol Prog Ser 38:89-99. doi:10.3354/Meps038089

Clarke A (1993) Seasonal acclimatization and latitudinal compensation in metabolism - do they exist. Funct Ecol 7:139-149. doi: $10.2307 / 2389880$

Clarke A (2003) Costs and consequences of evolutionary temperature adaptation. Trends Ecol Evol 18:573-581. doi:10.1016/j. tree.2003.08.007

Clarke A, Fraser KPP (2004) Why does metabolism scale with temperature? Funct Ecol 18:243-251. doi:10.1111/J. 0269-8463.2004.00841.X

Clarke A, Johnston NM (1999) Scaling of metabolic rate with body mass and temperature in teleost fish. J Anim Ecol 68:893-905. doi:10.1046/j.1365-2656.1999.00337.x

Davenport J (2000) Antarctic ecosystems: models for wider ecological understanding. Caxton Press, Christchurch, p 332

Doucet-Beaupre H, Dube C, Breton S, Pörtner HO, Blier PU (2010) Thermal sensitivity of metabolic enzymes in subarctic and temperate freshwater mussels (Bivalvia: Unionoida). J Therm Biol 35:11-20. doi:10.1016/j.jtherbio.2009.10.002

Gaffney PM, Diehl WJ (1986) Growth, condition and specific dynamic action in the mussel Mytilus edulis recovering from starvation. Mar Biol 93:401-409. doi:10.1007/Bf00401108

Hamburger K, Mohlenberg F, Randlov A, Riisgård HU (1983) Size, oxygen consumption and growth in the mussel Mytilus edulis. Mar Biol 75:303-306. doi:10.1007/Bf00406016

Hatcher A, Grant J, Schofield B (1997) Seasonal changes in the metabolism of cultured mussels (Mytilus edulis L.) from a
Nova Scotian inlet: the effects of winter ice cover and nutritive stress. J Exp Mar Biol Ecol 217:63-78. doi:10.1016/ S0022-0981(97)00042-7

Hjort C, Funder S (1974) The subfossil occurrence of Mytilus edulis L. in central East Greenland. Boreas 3:23-33. doi:10.1111/j.1502-3885.1974.tb00664.x

Holeton GF (1974) Metabolic cold adaptation of polar fish - fact or artifact. Physiol Zool 47:137-152

IPCC (2014) Climate Change 2014: Impacts, Adaptation, and Vulnerability. Part A: Global and Sectoral Aspects. Contribution of Working Group II to the Fifth Assessment Report of the Intergovernmental Panel on Climate Change [Field, C.B., V.R. Barros, D.J. Dokken, K.J. Mach, M.D. Mastrandrea, T.E. Bilir, M. Chatterjee, K.L. Ebi, Y.O. Estrada, R.C. Genova, B. Girma, E.S. Kissel, A.N. Levy, S. MacCracken, P.R. Mastrandrea, and L.L. White (eds.)]. Cambridge University Press, Cambridge, pp 1132

Jansen JM, Pronker AE, Kube S, Sokolowski A, Sola JC, Marquiegui MA, Schiedek D, Bonga SW, Wolowicz M, Hummel H (2007) Geographic and seasonal patterns and limits on the adaptive response to temperature of European Mytilus spp. and Macoma balthica populations. Oecologia 154:23-34. doi:10.1007/ S00442-007-0808-X

Johnston IA, Calvo J, Guderley H, Fernandez D, Palmer L (1998) Latitudinal variation in the abundance and oxidative capacities of muscle mitochondria in perciform fishes. J Exp Biol 201:1-12

Jones SJ, Lima FP, Wethey DS (2010) Rising environmental temperatures and biogeography: poleward range contraction of the blue mussel, Mytilus edulis L., in the western Atlantic. J Biogeogr 37:2243-2259. doi:10.1111/j.1365-2699.2010.02386.x

Jørgensen BB, Richardson K (1996) Eutrophication in coastal marine ecosystems. American Geophysical Union, Washington, D. C, p 267

Krause-Jensen D, Marba N, Olesen B, Sejr MK, Christensen PB, Rodrigues J, Renaud PE, Balsby TJS, Rysgaard S (2012) Seasonal sea ice cover as principal driver of spatial and temporal variation in depth extension and annual production of kelp in Greenland. Global Change Biol 18:2981-2994. doi:10.1111/J.1365-2486.2012.02765.X

Krogh A (1916) The respiratory exchange of animals and man. Longman, London, p 190

Lannig G, Eckerle LG, Serendero I, Sartoris FJ, Fischer T, Knust R, Johansen T, Pörtner HO (2003) Temperature adaptation in eurythermal cod (Gadus morhua): a comparison of mitochondrial enzyme capacities in boreal and Arctic populations. Mar Biol 142:589-599. doi:10.1007/S00227-002-0967-6

Livermore R, Eagles G, Morris P, Maldonado A (2004) Shackleton fracture zone: no barrier to early circumpolar ocean circulation. Geology 32:797-800. doi:10.1130/g20537.1

Munday PL, Jones GP, Pratchett MS, Williams AJ (2008) Climate change and the future for coral reef fishes. Fish Fish 9:261-285. doi:10.1111/j.1467-2979.2008.00281.x

Newell RC, Pye VI (1970) Seasonal changes in the effect of temperature on the oxygen consumption of the winkle Littorina littorea (L.) and the mussel Mytilus edulis L. Comp Biochem Physiol 34:367-383. doi:10.1016/0010-406X(70)90178-7

Nguyen KDT, Morley SA, Lai CH, Clark MS, Tan KS, Bates AE, Peck LS (2011) Upper temperature limits of tropical marine ectotherms: Global warming implications. Plos One 6 doi:10.1371/ journal.pone.0029340

Nielsen MG, Elmes GW, Kipyatkov VE (1999) Respiratory Q10 varies between populations of two species of Myrmica ants according to the latitude of their sites. J Insect Physiol 45:559-564. doi:10.1016/S0022-1910(98)00162-0

Olesen B, Krause-Jensen D, Marbà N, Christensen PB (2014) Eelgrass (Zostera marina L.) in subarctic Greenland: dense meadows with slow biomass turnover. Mar Ecol Prog Ser In review 
Parmesan C (2007) Influences of species, latitudes and methodologies on estimates of phenological response to global warming. Global Change Biol 13:1860-1872. doi:10.1111/j.1365-2486.2007.01404.x

Peck LS (2005) Prospects for survival in the Southern Ocean: vulnerability of benthic species to temperature change. Antarct Sci 17:497-507. doi:10.1017/S0954102005002920

Peck LS, Conway LZ (2000) The myth of metabolic cold adaptation: oxygen consumption in stenothermal Antarctic bivalves. Geol Soc Spec Publ 177:441-450. doi:10.1144/Gsl.Sp.2000.177.01.29

Peck LS, Clark MS, Morley SA, Massey A, Rossetti H (2009a) Animal temperature limits and ecological relevance: effects of size, activity and rates of change. Funct Ecol 23:248-256. doi:10.1111/j.1365-2435.2008.01537.x

Peck LS, Massey A, Thorne MAS, Clark MS (2009b) Lack of acclimation in Ophionotus victoriae: brittle stars are not fish. Polar Biol 32:399-402. doi:10.1007/s00300-008-0532-y

Peck LS, Morley SA, Richard J, Clark MS (2014) Acclimation and thermal tolerance in Antarctic marine ectotherms. J Exp Biol 217:16-22. doi:10.1242/jeb.089946

Pernet F, Tremblay R, Comeau L, Guderley H (2007) Temperature adaptation in two bivalve species from different thermal habitats: energetics and remodelling of membrane lipids. J Exp Biol 210:2999-3014. doi:10.1242/Jeb.006007

Perry AL, Low PJ, Ellis JR, Reynolds JD (2005) Climate change and distribution shifts in marine fishes. Science 308:1912-1915. doi:10.1126/science. 1111322

Pörtner HO (2002a) Climate variations and the physiological basis of temperature dependent biogeography: systemic to molecular hierarchy of thermal tolerance in animals. Comp Biochem Physiol A Physiol 132:739-761. doi:10.1016/S1095-6433(02)00045-4

Pörtner HO (2002b) Physiological basis of temperature-dependent biogeography: trade-offs in muscle design and performance in polar ectotherms. J Exp Biol 205:2217-2230

Pörtner HO (2006) Climate-dependent evolution of Antarctic ectotherms: an integrative analysis. Deep-Sea Res Part II 53:10711104. doi:10.1016/J.Dsr2.2006.02.015

Pörtner HO, Farrell AP (2008) Physiology and climate change. Science 322:690-692. doi:10.1126/science.1163156

Pörtner HO, Knust R (2007) Climate change affects marine fishes through the oxygen limitation of thermal tolerance. Science 315:95-97. doi:10.1126/science.1135471

Pörtner HO, Playle RC (1998) Cold ocean physiology. Cambridge University Press, Cambridge, p 498

Ricciardi A, Bourget E (1998) Weight-to-weight conversion factors for marine benthic macroinvertebrates. Mar Ecol Prog Ser 163:245-251. doi:10.3354/Meps163245

Riisgård HU, Randlov A (1981) Energy budgets, growth and filtration rates in Mytilus edulis at different algal concentrations. Mar Biol 61:227-234. doi:10.1007/Bf00386664

Schaefer J, Walters A (2010) Metabolic cold adaptation and developmental plasticity in metabolic rates among species in the Fundulus notatus species complex. Funct Ecol 24:1087-1094. doi:10.1111/j.1365-2435.2010.01726.x

Scholander PF, Flagg W, Walters V, Irving L (1953) Climatic adaptation in Arctic and tropical poikilotherms. Physiol Zool 26:67-92

Sejr MK, Petersen JK, Jensen KT, Rysgaard S (2004) Effects of food concentration on clearance rate and energy budget of the Arctic bivalve Hiatella arctica (L) at subzero temperature. J Exp Mar Biol Ecol 311:171-183. doi:10.1016/j.jembe.2004.05.005

Sejr MK, Blicher ME, Rysgaard S (2009) Sea ice cover affects interannual and geographic variation in growth of the Arctic cockle Clinocardium ciliatum (Bivalvia) in Greenland. Mar Ecol Prog Ser 389:149-158. doi:10.3354/Meps08200

Serreze MC, Barrett AP, Stroeve JC, Kindig DN, Holland MM (2009) The emergence of surface-based Arctic amplification. Cryosphere 3:11-19. doi:10.5194/tc-3-11-2009
Sinervo B, Mendez-de-la-Cruz F, Miles DB, Heulin B, Bastiaans E, Cruz MVS, Lara-Resendiz R, Martinez-Mendez N, CalderonEspinosa ML, Meza-Lazaro RN, Gadsden H, Avila LJ, Morando M, De la Riva IJ, Sepulveda PV, Rocha CFD, Ibarguengoytia N, Puntriano CA, Massot M, Lepetz V, Oksanen TA, Chapple DG, Bauer AM, Branch WR, Clobert J, Sites JW (2010) Erosion of lizard diversity by climate change and altered thermal niches. Science 328:894-899. doi:10.1126/science. 1184695

Somero GN, Devries AL (1967) Temperature tolerance of some Antarctic fishes. Science 156:257-258. doi:10.1126/science.156.3772.257

Sommer AM, Pörtner HO (2002) Metabolic cold adaptation in the lugworm Arenicola marina: comparison of a North Sea and a White Sea population. Mar Ecol Prog Ser 240:171-182. doi:10. 3354/Meps240171

Stillman JH (2003) Acclimation capacity underlies susceptibility to climate change. Science 301:65. doi:10.1126/science.1083073

Sukhotin AA, Abele D, Pörtner HO (2006) Ageing and metabolism of Mytilus edulis: populations from various climate regimes. J Shellfish Res 25:893-899. doi:10.2983/0730-8000

Terblanche JS, Clusella-Trullas S, Deere JA, Van Vuuren BJ, Chown SL (2009) Directional evolution of the slope of the metabolic rate - temperature relationship is correlated with climate. Physiol Biochem Zool 82:495-503. doi:10.1086/605361

Theisen BF (1973) The growth of Mytilus edulis L. (bivalvia) from Disko and Thule district, Greenland. Ophelia 12:19

Thompson RJ, Bayne BL (1972) Active metabolism associated with feeding in the mussel Mytilus edulis L. J Exp Mar Biol Ecol 9:111-124. doi:10.1016/0022-0981(72)90011-1

Thompson RJ, Bayne BL (1974) Some relationships between growth, metabolism and food in the mussel Mytilus edulis. Mar Biol 27:317-326. doi:10.1007/BF00394367

Thorarinsdottir GG, Gunnarsson K (2003) Reproductive cycles of Mytilus edulis L. on the west and east coasts of Iceland. Polar Res 22:217-223. doi:10.1111/j.1751-8369.2003.tb00108.x

Torres JJ, Somero GN (1988) Metabolism, enzymic activities and cold adaptation in Antarctic mesopelagic fishes. Mar Biol 98:169-180. doi:10.1007/Bf00391192

Walther GR, Post E, Convey P, Menzel A, Parmesan C, Beebee TJC, Fromentin JM, Hoegh-Guldberg O, Bairlein F (2002) Ecological responses to recent climate change. Nature 416:389-395. doi:10.1038/416389a

Watson S-A, Morley S, Bates A, Clark M, Day R, Lamare M, Martin S, Southgate P, Tan K, Tyler P, Peck L (2014) Low global sensitivity of metabolic rate to temperature in calcified marine invertebrates. Oecologia 174:45-54. doi:10.1007/s00442-013-2767-8

Wernberg T, Smale DA, Tuya F, Thomsen MS, Langlois TJ, de Bettignies T, Bennett S, Rousseaux CS (2013) An extreme climatic event alters marine ecosystem structure in a global biodiversity hotspot. Nat Clim Change 3:78-82. doi:10.1038/Nclimate1627

Węsławski JM, Kendall MA, Włodarska-Kowalczuk M, Iken K, Kędra M, Legezynska J, Sejr MK (2011) Climate change effects on Arctic fjord and coastal macrobenthic diversity-observations and predictions. Mar Biodiv 41:71-85. doi:10.1007/ s12526-010-0073-9

White CR, Alton LA, Frappell PB (2012) Metabolic cold adaptation in fishes occurs at the level of whole animal, mitochondria and enzyme. Proc R Soc B-Biol Sci 279:1740-1747. doi:10.1098/r spb.2011.2060

Wohlschlag DE (1960) Metabolism of an Antarctic fish and the phenomenon of cold adaptation. Ecology 41:287-292. doi: $10.2307 / 1930217$

Zwerschke N, Bollen M, Molis M, Scrosati R (2013) An environmental stress model correctly predicts unimodal trends in overall species richness and diversity along intertidal elevation gradients. Helgol Mar Res 67:663-674. doi:10.1007/s10152-013-0352-5 